Imágenes en Urología

\title{
Litiasis pseudocoraliforme en riñón con doble sistema excretor incompleto y megauréter doble
}

Cristóbal Ramírez Sevilla, Miguel A. Barranco Sanz, Juan Llopis Manzanera, Zdenek Stanek*, José A. Romero Martín

Servicio de Urología y Radiodiagnóstico*. Consorci Sanitari del Maresme. Hospital de Mataró (Barcelona)

$\mathrm{M}$ ujer de 42 años de edad con antecedentes patológicos de obesidad, fibromialgia, síndrome ansioso-depresivo y cólico nefrítico secundario a litiasis renal derecha que recibió tratamiento con litotricia.

Acudió a Urgencias por dolor lumbar bilateral tipo cólico de predominio derecho y síndrome miccional sin fiebre de 3-4 días de evolución. A la exploración física presentaba puñopercusión lumbar derecha positiva con ausencia de signos de irritación peritoneal. En la analítica sanguínea no se objetivaban alteraciones significativas y en el sedimento urinario destacaba la presencia de microhematuria.

En la radiografía simple de abdomen se objetivaba la presencia de litiasis pseudocoraliforme renal derecha a nivel de tercio medio e inferior. La ecografía renal informaba de microlitiasis renales izquierdas y litiasis calicilares múltiples a nivel del riñón derecho con discreta ectasia secundaria del sistema excretor. En la pielografía endovenosa se confirmó la presencia de litiasis pseudocoraliforme derecha con eliminación del contraste bilateral y simétrica con discreta ectasia del hemirriñón inferior derecho, con presencia de doble sistema excretor derecho incompleto con megauréter doble hasta nivel ilíaco, sin objetivar defectos de replección ni causas obstructivas a este nivel.

Durante el ingreso la paciente permaneció estable y afebril con mejoría deldolor lumbar con analgesia, por lo que se decició el alta y traslado a centro con Unidad de Litiasis para tratamiento.

Correspondencia autor: Dr. Cristóbal Ramírez Sevilla Servicio de Urología.

Consorci Sanitari del Maresme. Hospital de Mataró Carretera de Cirera, s/n 08304 Mataro, Barcelona Tel.: 937417700

E-mail autor: cjrs70@yahoo.com

Información artículo: Imágenes en Urología

Trabajo recibido: octubre 2007

Trabajo aceptado: noviembre 2007

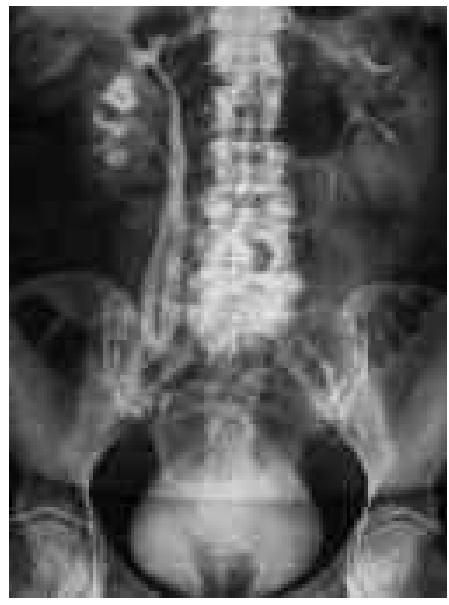

FIGURA 1

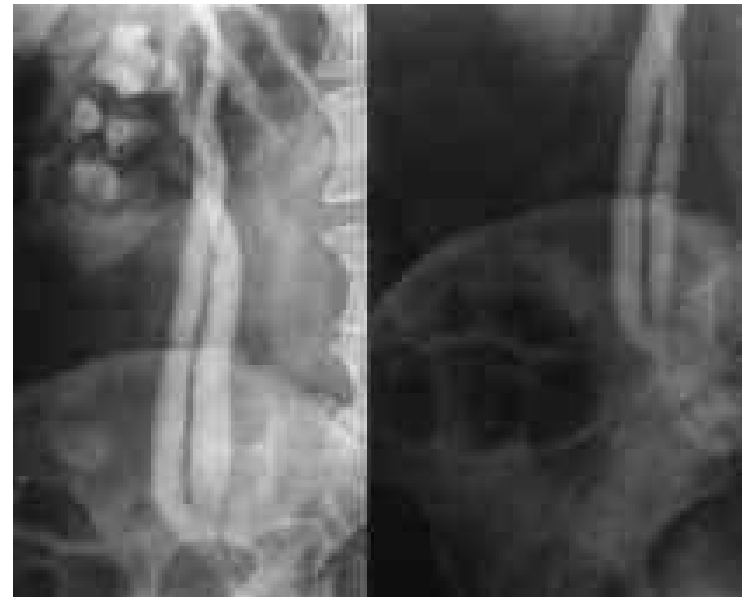

FIGURA 2

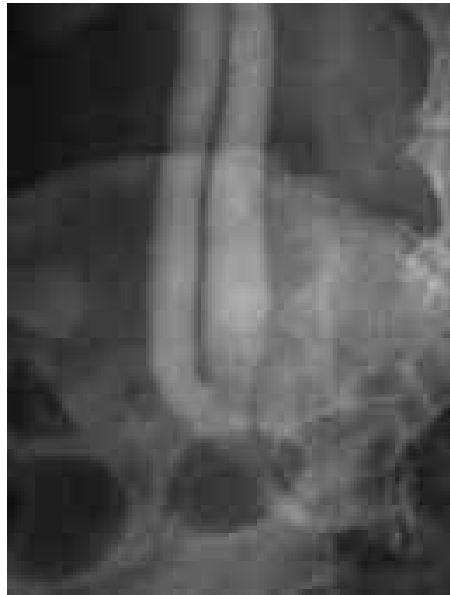

FIGURA 3 